\title{
Perancangan Alat Penghitung Jumlah Pengunjung Konser Berbasis Mikrokontroler At89s51
}

\author{
Eko Setia Budi \\ STMIK Nusa Mandiri Jakarta, Indonesia \\ Jl. Damai No.8 Warung Jati Barat, Jakarta Selatan, 12950, Indonesia \\ eko.etb@bsi.ac.id
}

\begin{abstract}
Abstrak
Di era globalisasi sekarang ini, teknologi informasi melaju dengan cepatnya. Adapun komputer yang merupakan peralatan yang diciptakan untuk mempermudah pekerjaan manusia, saat mencapai kemajuan baik di dalam pembuatan hardware maupun software. Untuk itulah saya sebagai penulis mencoba Tugas Akhir untuk pembuatan alat yang disebut "Alat Penghitung Jumlah Pengunjung Konser Berbasis Mikrokontroler AT89S51". Alat ini berfungsi sebagai penghitung jumlah banyaknya pengunjung yang datang ke suatu tempat. Rincian informasi yang ada akan mudah diterima penyedia tempat sebagai data rekap banyaknya pengunjung secara otomatis. Untuk itu saya disini mencoba mempraktekan dan membuat alat ini sebagai bahan uji coba dan sebagai pemberi inspirasi. Perancangan alat ini sangat sesuai dan memiliki solusi yang baik untuk membantu mendapatkan data tanpa harus menghitung dan mengingat dalam pikiran secara manual.
\end{abstract}

Kata Kunci: AT89S51, Mikrokontroler, Pengunjung Konser, Alat Penghitung

\begin{abstract}
In the current era of globalization, information technology advanced so quickly. The computer is the equipment created to facilitate the work of man, while achieving good progress in the manufacture of hardware and software. For that I am as a writer tries final project for the manufacture of tools called "Tool Counters Number of Visitors Microcontroller AT89S51Based Concert". This tool serves as a counter number of the many visitors who come to a place. Details of existing information will be readily accepted as a provider of data recap many visitors automatically. For that I am here trying to practice and make this tool as a pilot and as inspirational. The design of this tool is very fit and have a good solution to help get the data without having to calculate and remember in mind manually.
\end{abstract}

Keywords:AT89S51, Microcontroller, Number of Visitors Concerts, Counters Tools

\section{PENDAHULUAN}

Semakin lama teknologi yang ada saat ini semakin pesat saja dan mendunia. Dengan adanya teknologi saat ini, apapun bisa dilakukan. Misal seperti bekerja, berkunjung ke acara tertentu, berbelanja, memasuki perparkiran, melewati jalan tol, dan lainnya yang memiliki banyak pengunjung datang ke tempat tersebut. Tingginya mobilitas manusia yang ada, mereka selalu pada waktu kesibukan dalam sehari - hari untuk melakukan banyak macam kegiatan. Kegiatan seperti ini sudah tak asing bagi kita, setiap harinya bisa saja berjuta - juta orang datang ketempat tersebut dengan `tujuan tertentu. Namun semakin banyak kapasitas yang memasuki tempat tersebut semakin sulit untuk menghitung jumlah banyaknya pengunjung yang ada.

Penghitungan jumlah yang dilakukan memungkinkan untuk menerima data setiap harinya sebagai rekap data atau rating pada penyedia layanan / penyedia tersebut. Salah satu contoh yang ramai dikunjungi adalah acara konser. Konser merupakan salah satu acara musik yang banyak disukai masyarakat. Dengan membeli tiket konser dan lalu masuk kedalam lokasinya. Akan tetapi tidak adanya pekerjaan penghitungan mungkin kurang efektif, karena dimana pun pasti sebagai penyedia akan memerlukan data sebagai hasil untuk melihat apakah muatan yang ada menghasilkan keuntungan atau kerugian. Selain itu, kemungkinan adanya suatu alat yang dapat menghitung jumlah pengunjung dimana saja dapat membantu proses kerja yang mulus untuk suatu penyedia layanan.

\section{METODE PENELITIAN}

Untuk melengkapi data - data yang diperlukan untuk penyusunan penelitian ini, maka penulis melakukan metode penelitian berupa:

\subsection{Metode Observasi.}

Dalam metode ini, saya melakukan tes pada "Alat Penghitung Jumlah Pengunjung Konser Berbasis Mikrokontroler AT89S51" tersebut untuk memperoleh data dari beberapa bagian perangkat keras dan perangkat lunak sehingga dapat diketahui apakah alat sudah bekerja sesuai yang diinginkan. Selain itu saya melakukan Eko Setia Budi | http://ejurnal.stmik-budidarma.ac.id/index.php/mib | Page | 47 
wawancara dengan pihak - pihak yang berkompeten untuk mendapatkan gambaran dan informasi secara jelas terhadap berbagai masalah dalam penulisan.

\subsection{Wawancara}

Penulis melakukan wawancara kepada narasumber tentang apa yang penulis temukan di lapangan yang tidak diketahui dan dijadikan sebagai bahan pembelajaran. informasi yang di dapat dengan metode ini merupakan mengenai proses dan prosedur-prosedur system yang dilakukan saat ini.

\subsection{Studi pustaka}

Dalam teknik ini, penulis mencari referensi yang berkaitan dengan laporan yang akan ditulis. Penulis mencari referensi pada beberapa sumber seperti: di perpustakaan, buku-buku komputer dan browsing di internet.

\subsubsection{Resistor}

Menurut Tim Pustena ITB. (2011), resistor merupakan komponen elektronika dasar yang paling banyak dipakai. Resistor digunakan untuk membatasi arus dalam sebuah rangkaian. Resistor ini memiliki kode warna pada badannya untuk menunjukkan nilai dari resistor tersebut. Satuan yang dipakai untuk menentukan besar kecilnya nilai resistor adalah Ohm atau disingkat dengan huruf Yunani OMEGA $(\Omega)$. Nilai satuan besaran yang dipergunakan untuk menentukan besarnya nilai resistor adalah :

a) 1 Mega Ohm $(\mathrm{M} \Omega)=1.000 .000 \mathrm{Ohm}$.

b) 1 Kilo Ohm $(\mathrm{K} \Omega)=1.000 \mathrm{Ohm}$.

Resistor dapat dibagi menjadi beberapa jenis resistor, namun disini hanya disebutkan 3 jenis saja. Berikut ini penjelasan dari resistor tersebut:

a. Resistor Tetap.

Menurut Tim Pustena ITB. (2011), resistor tetap adalah resistor yang nilai besarannya sudah ditetapkan oleh pabrik pembuatnya dan tidak dapat diubah - ubah. Pada umumnya bentuk fisik dari resistor jenis ini bentuknya bulat panjang dan kecil.

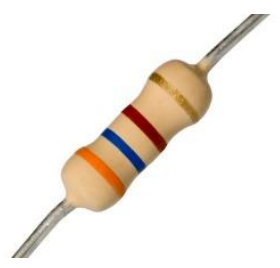

Gambar 1. Resistor

Sumber : http://develissimo.com/en/online-shop/product/resistor-carbon-film/

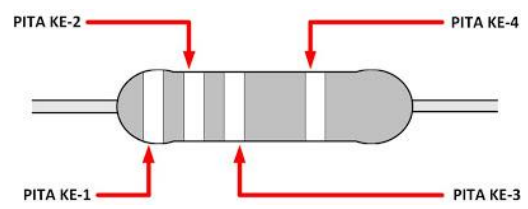

Gambar 2. Sistem Kode Warna 4 Pita

Sumber : http://komponenelektronika.biz/kode-warna-resistor.html

Sistem kode warna 4 pita ini merupakan kode warna sering digunakan dalam alat elekrtonika yang terdiri dari 4 pita warna melingkari badan resistor. Dua pita yang terdapat pada bagian depan berfungsi utuk informasi dua digit harga resistansi. Sedangkan pita ketiga merupakan faktor pengali (jumlah nol yang ditambahkan setelah dua digit resistansi) dan pita keempat digunakan untuk toleransi harga resistansi. Berikut tabel warna resistor Hi-Co-Me-OKu-Hi-Bi-U-A-Pu-E-Pe-T:

\begin{tabular}{|c|c|c|c|c|}
\hline \multicolumn{7}{|c|}{ Tabel 1. Kode Warna 4 Pita } \\
\hline KODE WARNA & PITA KE -1 & PITA KE -2 & PITA KE -3 & PITA KE -4 \\
\hline HITAM & 0 & 0 & $10^{0}$ & - \\
\hline COKLAT & 1 & 1 & $10^{1}$ & - \\
\hline MERAH & 2 & 2 & $10^{2}$ & - \\
\hline ORANGE & 3 & 3 & $10^{3}$ & - \\
\hline
\end{tabular}

Eko Setia Budi | http://ejurnal.stmik-budidarma.ac.id/index.php/mib | Page | 48 


\begin{tabular}{|c|c|c|c|c|}
\hline KODE WARNA & PITA KE -1 & PITA KE - 2 & PITA KE - 3 & PITA KE -4 \\
\hline KUNING & 4 & 4 & $10^{4}$ & - \\
\hline HIJAU & 5 & 5 & $10^{5}$ & - \\
\hline BIRU & 6 & 6 & $10^{6}$ & - \\
\hline UNGU & 7 & 7 & $10^{7}$ & - \\
\hline ABU - ABU & 8 & 8 & $10^{8}$ & - \\
\hline PUTIH & 9 & 9 & $10^{9}$ & $5 \%$ \\
\hline EMAS & - & - & $10^{-1}$ & $10 \%$ \\
\hline PERAK & - & - & $10^{-2}$ & $20 \%$ \\
\hline Tak Berwarna & - & - & - & - \\
\hline
\end{tabular}

Sumber : http://komponenelektronika.biz/kode-warna-resistor.html

Contoh :

Pita ke-1 = Hijau (5), Pita ke-2 = Biru (6), Pita ke-3 = Perak $\left(10^{-2}\right)$, Pita ke-4 = Emas (5\%).

$56 \times 10^{-2} \pm 5 \%$

$56: 100 \pm 5 \%$

$0,56 \Omega \pm 5 \%$ (Berarti nilainya adalah $0,56 \Omega$, dengan Toleransi $5 \%$ ).

b. Resistor Tidak Tetap.

Menurut Tim Pustena ITB. (2011), resistor tidak tetap adalah resistor yang nilai tahanannya dapat diatur sesuai dengan kebutuhan. Maksud dan tujuan dari pemasangan resistor tidak tetap dalam suatu rangkaian adalah dengan tujuan untuk mengatur besar kecilnya arus dan tegangan dalam suatu rangkaian, sebagai pembagi tegangan dan sebagai pembagi arus.

c. Resistor Array.

Adapun jenis resistor lainnya, yaitu resistor yang di pak khusus. Didalam resistor tersebut sebenarnya hanya sekumpulan resistor yang disusun sejajar dan dikenal dengan nama array resistor. Resistor ini dibuat dengan tujuan khusus. Resistor jenis ini dibuat dari sekumpulan resistor yang dipaket rapi dengan salah satu kakinya digabungkan, sehingga jumlah kakinya lebih sedikit dan lebih pendek. Salah satu ujung array resistor ini merupakan pin umum untuk membagi tegangan atau digunakan sebagai pemisah tegangan.

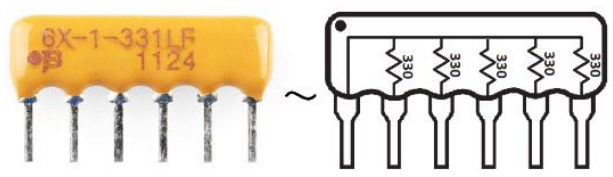

Gambar 3. Resistor Array

Sumber : http://www.hendriono.com/blog/post/resistor

\subsubsection{Trimpot}

Trimpot adalah singkatan dari trimmer potensiometer, bentuknya kecil dan nilai tahanannya dapat dirubah - rubah dengan cara memutar lubang coakan di tengah dengan menggunakan obeng kecil.

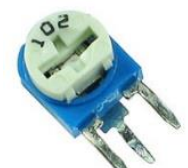

Gambar 4. Trimpot

Sumber : https://www.futurlec.com/Potentiometers/TRIMV10Kpr.shtml

\subsubsection{Kapasitor.}

Menurut ST, Malik Ibnu Moh., (2006), fungsi dari kapasitor adalah menyimpan arus listrik. Seperti juga halnya resistor, kapasitor termasuk salah satu komponen pasif yang banyak dipergunakan dalam membuat rangkaian elektronika. Kapasitor sendiri berasal dari kata kapasitance atau kapasitas yang artinya kemampuan untuk menyimpan arus listrik. 
Dalam istilah elektronika yaitu sebagai muatan listrik, jadi kapsitor adalah suatu komponen yang dapat diisi dengan muatan listrik kemudian disimpan untuk sementara waktu dan selanjutnya muatan tersebut dikosongkan/dibuang melalui suatu sistem atau dihubungkan ke bumi. Kapasitor juga ada yang dapat dirubah kapasitasnya. Seperti juga halnya dengan resistor, komponen kapasitor juga memiliki nilai satuan yang dinyatakan dengan satuan Farad.

Satuan Farad adalah satuan yang sangat besar dan jarang dipergunakan dalam percobaan. Dalam praktek biasanya dipergunakan satuan Farad dalam bentuk pecahan seperti berikut :
a. 1 Farad $(\mathrm{F})$
$=1.000 .000 \mu \mathrm{F}($ Micro Farad $)$.
b. 1 Micro Farad $(\mu \mathrm{F})=1.000 \mathrm{nF}$ (Nano Farad).
c. 1 Nano Farad $(\mathrm{nF})=1.000 \mathrm{pF}($ Pico Farad $)$.

Selain itu ada 2 jenis kapasitor, antara lain :

1) Kapasitor Polar.

Kapasitor polar mempunyai kutub positif dan negatif. Yang arti pada polarnya adalah pemasangan pada kutub positif dan negatif tidak boleh terbalik, bila terbalik kapasitor pun bisa rusak bahkan meledak. Satuan kapasitor ialah farad $(\mathrm{F})$, milifarad $(\mathrm{mF})$, mikro farad $(\mu \mathrm{F})$, nanofarad $(\mathrm{nF})$, dan pikofarad (pF). Konversi nilai kapasitansinya sama dengan konversi satuan tahanan listrik.

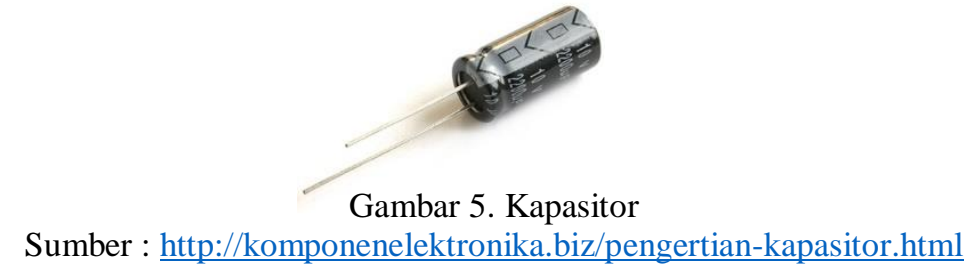

2) Kapasitor Tak Berkutup (Non Polar).

Berbeda dengan kapasitor sebelumnya, kapasitor yang satu ini bebas digunakan alias tidak negatif / tidak positf. Artinya dapat digunakan tanpa menentukan arah kutub, bila tertukar pun tidak masalah. Kapasitor ini termasuk murah dan mudah didapat. Tersedia dari besaran $\mathrm{pF}$ sampai beberapa $\mathrm{uF}$, yang biasanya untuk aplikasi rangkaian yang berkenaan dengan frekuensi tinggi.

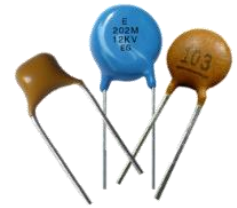

Gambar 6. Kapasitor Non Polar

Sumber : http://www.capacitorguide.com/ceramic-capacitor/

\subsubsection{XTAL}

XTAL atau yang biasa disebut dengan kristal ini memiliki peran yang sangat penting. Komponen elektronika ini berfungsi untuk membangkitkan frekuensi osilasi dengan stabilitas yang sangat tinggi. Frekuensi osilasi didapat dari efek piezoelectric. Bahan yang biasa digunakan untuk memperoleh efek piezoelectric diantaranya kwarsa, garam Rochelle dan tourmaline. Bahan yang banyak digunakan adalah kristal kwarsa.

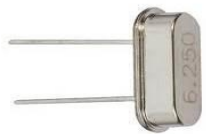

Gambar 7. XTAL

Sumber : http://san-eshop.com/index.php?main_page=index\&cPath=225

\subsubsection{Dioda.}

Menurut ST, Malik Ibnu Moh., (2006), dioda merupakan komponen elektronika yang dibuat dari semikonduktor. Secara umum (berdasarkan bahan yang membuatnya) dioda dibagi menjadi dioda germanium dan dioda silicon. Semikonduktor adalah bahan yang dibuat dari bahan PN Junction, yiatu bahan campuran yang terdiri bahan positif (P Type) yang bermuatan negatif dan bahan positif dan bahan negatif (N Type) yang bermuatan negatif. Bahan positif ( $\mathrm{P}$ Type) adalah bahan campuran terdiri dari germanium atau silicon dengan aluminium dan merupakan 
bahan yang kekurangan elektron dan bersifat positif. Bahan negatif ( $\mathrm{N}$ Type) adalah bahan campuran yang terdiri dari germanium atau silicon dengan fosfor dan merupakan bahan yang kelebihan elektron dan bersifat negatif. Jika kedua bahan tersebut dipertemukan, maka akan terbentuklah sebuah komponen aktif yang disebut dioda. Dalam kegunaannya, dioda akan bekerja jika diberikan arus bolak-balik (AC) selain itu juga dapat berfungsi sebagai penyearah. Sifat dioda hanya dapat mengalirkan arus listrik dalam satu arah saja, apabila kutub anoda diberi sumber arus positif (+) dan kutub katoda diberi sumber arus negatif (-) sedangkan bila kutub anoda diberi arus negatif (-) dan kutub katodanya diberi arus positif (+) maka dioda akan bersifat menahan arus listrik. Dioda terdapat 3 macam, antara lain :

\section{a. Dioda Silikon.}

Dioda silikon adalah dioda kecil yang berbentuk tabung dengan garis putih yang melingkari salah satu kutubnya, lebih tepatnya pada bagian positif. Dioda jenis ini biasanya digunakan sebagai penyearah pada rangkaian adaptor.

Gambar 8. Dioda Silikon

Sumber : http://www.mammothelectronics.com/1N4004-p/120-1019.htm

\section{b. Dioda LED}

Dioda LED ini mungkin sudah tidak asing bagi kita yang hobi dalam robotik. Dioda ini memiliki keistimewaan tersendiri, yaitu dapat memancarkan cahaya jika dialiri arus listrik. Cahaya yang dihasilkan (terang atau redup) tergantung dari besar arus yang diberikan.

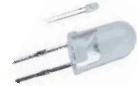 \\ Gambar 9. Dioda LED \\ Sumber : http://www.electronics-lab.com/blog/?p=5058}

\subsubsection{Transistor.}

Transistor adalah komponen elektronika yang memiliki 3 kaki, yaitu emitor, basis dan kolektor. Komponen ini digunakan sebagai pemutus, penyambung, stabilitasi tegangan, dan masih banyak lagi fungsi lainnya. Selain itu, transistor juga bisa digunakan sebagai kran listrik sehingga dapat mengalirkan listrik dengan sangat akurat.

Ada dua macam resistor, yaitu :

a. Transisror PNP (Positive Negative Positive).

b. Transistor NPN (Negative Positive Negative).

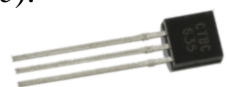

Gambar 10. Transistor

Sumber : http://www.zmescience.com/research/technology/quantum-materials-transistor-18092014/

\subsubsection{Teori IC Digital / IC Analog / IC Penguat.}

IC (Integrated Circuit) adalah suatu komponen elektronika yang mempunyai bentuk kaki mirip dengan binatang kaki seribu. Dalam bidang elektronika sering ditemukan berbagai jenis komponen IC yang dipasang, baik dalam rangkaian populer maupun rangkaian logika komputer. Jenis IC dapat dikelompokan berdasarkan pemakaiannya dan bahan semikonduktor yang dipergunakan, yaitu : Rangkaian digital (logika) dan Rangkaian analog (linier).

a. IC AT89S51.

IC mikrokontroler ini adalah IC yang keluar dari keluarga ATMEL yang memiliki 40 pin. Mikrokontroler ini sangat cukup terkenal dan IC ini memiliki suatu fitur sendiri yaitu ISP (In-System Programmable Flash Memory). Artinya bisa memungkinkan dapat diisi langsung pada suatu sistem elektronik tanpa menggunakan Downloader Board. Program dapat langsung diisi melalui kabel ISP yang dihubungkan dengan paralel port pada suatu Personal Computer.

Gambar 11. IC AT89S51 
Selain itu, adapun penjelasan tentang datasheet pada IC AT89S51 serta fungsi yang ada. Berikut penjelasannya :

\begin{tabular}{|c|c|c|c|}
\hline P1.0 & 1 & 40 & VCC \\
\hline $\mathrm{P} 1.1$ & 2 & 39 & P0.0(AD0) \\
\hline $\mathrm{P} 1.2$ & 3 & 38 & P0.1(AD1) \\
\hline $\mathrm{P} 1.3$ & 4 & 37 & P0.2(AD2) \\
\hline $\mathrm{P} 1.4$ & 5 & 36 & P0.3(AD3) \\
\hline (MOSI)P1.5 & 6 & 35 & P0.4(AD4) \\
\hline (MISO)P1.6 & 7 & 34 & P0.5(AD5) \\
\hline (SCK)P1.7 & 8 & 33 & P0.6(AD6) \\
\hline RST & 9 & 32 & P0.7(AD7) \\
\hline (RXD)P3.0 & 10 & 31 & EA/VPP \\
\hline (TXD)P3.1 & 11 & 30 & ALE/PROG \\
\hline (INT0)P3.2 & 12 & 29 & PSEN \\
\hline (INT1)P3.3 & 13 & 28 & $\mathrm{P} 2.7(\mathrm{~A} 15)$ \\
\hline (T0)P3.4 & 14 & 27 & P2.6(A14) \\
\hline (T1)P3.5 & 15 & 26 & $\mathrm{P} 2.5(\mathrm{~A} 13)$ \\
\hline (WR)P3.6 & 16 & 25 & $\mathrm{P} 2.4(\mathrm{~A} 12)$ \\
\hline (RD)P3.7 & 17 & 24 & $\mathrm{P} 2.3(\mathrm{~A} 11)$ \\
\hline XTAL2 & 18 & 23 & $\mathrm{P} 2.2(\mathrm{~A} 10)$ \\
\hline XTAL1 & 19 & 22 & P2.1(A9) \\
\hline GND & 20 & 21 & $\mathrm{P} 2.0(\mathrm{~A} 8)$ \\
\hline
\end{tabular}

Sumber : http://www.atmel.com/devices/at89s51.aspx

1) Pin 1 Sampai 8 .

Pin 1 sampai 8 ini adalah port 1 yang merupakan jalur untuk Input / Output 8 bit dari dua arah. Dari internal pullup yang dapat digunakan untuk segala macam keperluan, ialah dipakai sebagai jalur alamat pada saat pemrograman dan verifikasi.

2) Pin 9 .

Pin 9 digunakan untuk masukan reset (aktif tinggi), pulsa transisi dari rendah langsung ke tinggi akan me-reset mikrokontroler ini.

3) Pin 10 Sampai 17.

Pin 10 sampai 17 ini adalah port 3 yang merupakan jalur untuk Input / Output 8 bit dari dua arah. Dengan internal pull-ups yang dapat digunakan sebagai pengganti. Bila fungsi pengganti tidak dioperasikan, maka ini dapat digunakan untuk port paralel 8 bit serbaguna. Selain itu sebagian port 3 dapat difungsikan sebagai sinyal kontrol pada saat proses pemrograman dan verifikasi. Ada beberapa fungsi penggantinya seperti pada tabel di bawah ini :

Tabel 3. Fungsi Pengganti Dari Port 3

\begin{tabular}{|c|c|c|}
\hline Bit & Nama & Fungsi Alternatif \\
\hline P3.0 & RXD & Untuk input data port serial \\
\hline P3.1 & TXD & Untuk output data port serial \\
\hline
\end{tabular}

Eko Setia Budi | http://ejurnal.stmik-budidarma.ac.id/index.php/mib | Page | 52 


\begin{tabular}{|c|c|c|}
\hline Bit & Nama & Fungsi Alternatif \\
\hline P3.2 & INT0 & Interupsi eksternal 0 \\
\hline P3.3 & INR1 & Interupsi eksternal 1 \\
\hline P3.4 & T0 & Input eksternal waktu / pencacah 0 \\
\hline P3.5 & T1 & Input eksternal waktu / pencacah 1 \\
\hline P3.6 & WR & Jalur menulis memori data eksternal \\
\hline P3.7 & RD & Jalur membaca memori data eksternal \\
\hline
\end{tabular}

4) Pin 18 Sampai 19.

Pin 18 sampai 19 ialah input-an ke penguat osilator berpenguat tinggi. Pada mikrokontroler ini memiliki semua rangkaian osilator yang diperlukan untuk serpih yang sama (on chip) kecuali rangkaian kristal yang mengendalikan frekuensi osilator. Karenanya 18 dan 19 sangat diperlukan untuk dihubungkan dengan kristal. Selain itu XTAL 1 dapat juga sebagai input untuk inverting oscilator amplifier dan input ke rangkaian internal clock. Sedangkan XTAL 2 merupakan output dari inverting oscilator amplifier.

5) Pin 20.

Merupakan ground sumber tegangan negatif yang diberi simbol GND.

6) Pin 21 sampai 28.

Pin 21 sampai 28 ini adalah port 2 yang merupakan jalur Input / Output 8 bit dua arah dengan internal pull-ups. Saat pengambilan data dari program memori eksternal atau selama mengakses data memori eksternal yang menggunakan alamat 16 bit (MOVX @ DPTR), port 2 berguna sebagai jalur alamat tinggi (A8 - A15). Sedangkan pada saat mengakses ke data memori eksternal yang menggunakan alamat 8 bit (MOVX @ R1), port 2 mengeluarkan isi dari P2 pada Special Function Register.

7) Pin 29.

Program Store Enable (PSEN) berfungsi sebagai sinyal pengontrol untuk mengakses program memori eksternal masuk ke dalam bus selama proses Input / Output instruksi (fetching).

8) Pin 30.

Address Latch Enable (ALE) / PROG berfungsi sebagai penahan alamat memori eksternal (pada port 1) selama mengakses ke memori eksternal. Pin ini juga sebagai pulsa / sinyal input pemograman (PROG) selama pemograman berjalan.

9) Pin 31.

External Access Enable (EA) berguna sebagai sinyal kontrol untuk pembacaan memori program. Jika diset rendah (Low) maka mikrokontroler akan melaksanakan seluruh instruksi dari memori program eksternal, sedangkan apabila diset tinggi (High) maka mikrokontroler akan menjalankan perintah dari memori program internal ketika isi program counter kurang dari 4096. Pin ini juga berfungsi sebagai tegangan pemograman $\left(V_{P P}=+12 \mathrm{~V}\right)$ selama proses pemrograman.

10) Pin 32 sampai 39.

Pin 32 sampai 39 ini adalah port 0 yang merupakan jalur Input / Output 8 bit open colector, dapat juga difungsikan sebagai multipleks bus alamat rendah dan bus data selama adanya akses ke memori program eksternal. Pada saat proses pemrograman dan verifikasi port 0 digunakan sebagai jalur data. External pull-ups sangat dibutuhkan selama proses verifikasi.

11) Pin 40.

Merupakan sumber arus positif tegangan yang diberi simbol VCC

b. IC AN7805.

IC regulator yang satu ini banyak pemakainya serta mikrokontroler ini sangat bermanfaat untuk para penggunanya. Manfaat menggunakan IC ini adalah dapat menurunkan tegangan DC menjadi $5 \mathrm{~V}$ secara otomatis. Tegangan yang sudah ditentukan itu biasanya digunakan untuk alat dalam rangkaian yang tidak terlalu besar dan tegangan yang standar.

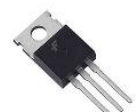

Gambar 12. IC AN7805

Sumber : http://www.amazon.com/7805-5V-Voltage-Regulator-TO-220/dp/B0002ZPXJ6

c. IC CD4094BE.

IC CD4094BE ini adalah jenis dari IC shift register yang digunakan sebagai pemasukkan data secara serial dan selanjutnya data dikeluarkan secara paralel. IC ini memliki 16 pin yang tersedia. 


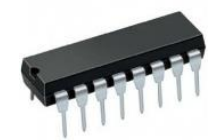

Gambar 13. IC CD4094BE

Sumber : http://www.ingenieriaselca.com/product.php?id_product=367

Berikut ini adalah datasheet pada IC CD4094BE, ialah :

Tabel 4. DataSheet IC CD4094BE

\begin{tabular}{|r|c|l|l|}
\hline Strobe & 1 & 16 & VDD \\
\hline Data & 2 & 15 & $\begin{array}{l}\text { Output } \\
\text { Enable }\end{array}$ \\
\hline Clock & 3 & 14 & Q5 \\
\hline Q1 & 4 & 13 & Q6 \\
\hline Q2 & 5 & 12 & Q7 \\
\hline Q3 & 6 & 11 & Q8 \\
\hline Q4 & 7 & 10 & Q'S \\
\hline VSS & 8 & 9 & QS \\
\hline
\end{tabular}

Sumber : http://www.alldatasheet.com/datasheet-pdf/pdf/26897/TI/CD4094BE.html

\subsection{Komponen Input.}

a. Transformator / Trafo.

Transformator berfungsi untuk mengubah suatu tegangan bolak - balik (AC) menjadi tegangan searah (DC) tegangan yang dihasilkan bisa jadi lebih rendah atau lebih tinggi. Transformator terdiri dari kumparan primer dan kumparan sekunder.

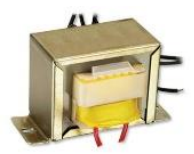

Gambar 14. Trafo

Sumber : http://www.eotomasyon.com/16v-40w-trafo.html

b. Inframerah (Infrared).

Inframerah (Infrared) adalah cahaya elektromagnet yang panjang gelombangnya lebih dari pada cahaya tampak yaitu antara $700 \mathrm{~nm}$ dan $1 \mathrm{~mm}$. Cahaya inframerah merupakan cahaya yang tidak dapat dilihat tanpa bantuan alat. Salah satu alat yang dibutuhkan adalah spektroskop. Jika dilihat dengan alat ini (spektroskop), maka radiasi cahaya inframerah akan tampak pada spectrum elektromagnet dengan panjang gelombang di atas panjang gelombang cahaya inframerah. Dengan panjang gelombang ini maka cahaya inframerah ini akan tidak tampak oleh mata namun radiasi panas yang ditimbulkannya masih bisa terasa. Inframerah dapat dibedakan menjadi tiga daerah yaitu

1) Near Infra Merah

2) Mid Infra Merah

3) Far Infra Merah

$0.75-1.5 \mu \mathrm{m}$.

$1.50-10 \mu \mathrm{m}$.

$10-100 \mu \mathrm{m}$.

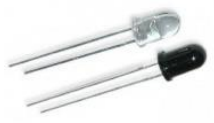

Gambar 15. Infrared

Sumber : http://www.shelfkey.com/orderProduct.aspx?prodid=6637\&partno=IR-RX/TX 


\subsection{Komponen Output}

a. LED.

LED (Light Emitting Diodes) adalah dioda yang ditempatkan dalam suatu wadah yang tembus - pandang yang akan menyala bila dialiri dengan arus listrik. Tegangan yang melalui dioda ini besarnya antara 1,6 Volt dan 2,4 Volt yang ditentukan oleh tipe - tipenya. Arus yang dibutuhkan adalah sebesar 15 sampai 25 mA. Bagian positif pada LED biasanya di tandai dengan kakinya yang lebih panjang.

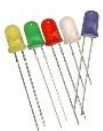

Gambar 16. LED

Sumber : https://solarbotics.com/product/sled/

b. Seven Segment.

Seven segment adalah segment - segment atau papan layar yang digunakan untuk menampilkan angka. Seven segment ini tersusun atas 7 bagian batang LED yang disusun membentuk angka 8 dengan menggunakan huruf 'a' sampai 'g' yang biasa disebut dot matrix. Setiap segment ini terdiri dari 1 atau 2 LED. Seven Segment merupakan gabungan dari 7 buah LED yang dirangkaikan menampilkan suatu angka.

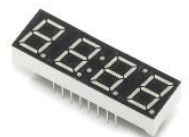

Gambar 17. Seven Segment

Sumber : https://www.sparkfun.com/products/9483

\section{c. Buzzer.}

Buzzer adalah sebuah komponen elektronika yang berfungsi untuk mengubah getaran listrik menjadi getaran suara. Prinsip kerja buzzer hampir sama dengan loud speaker. Buzzer terdiri dari kumparan yang terpasang pada diafragma dan kemudian kumparan tersebut dialiri arus sehingga menjadi elektromagnet. Buzzer biasa digunakan sebagai indikator bahwa proses telah selesai atau terjadi suatu kesalahan pada sebuah alat (alarm).

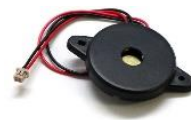

Gambar 18. Buzzer

Sumber : http://store.uav-solutions.com/3dr-buzzer-for-pixhawk/

\subsection{Mikrokontroler / Interfacing}

Disini akan dibahas cara berjalannya alat penghitung jumlah pengunjung konser berbasis mikrokontroler AT89S51.

a. Input pada alat ini adalah terdiri dari sensor infrared TX dan RX. Sensor ini diletakan pada pintu masuk dan pintu keluar. Yang berguna untuk mendeteksi banyaknya pengunjung yang masuk dan keluar pada lokasi konser.

b. Output yang dihasilkan berupa seven segmen, LED, dan buzzer. Seven segmen berfungsi sebagai keluaran berupa angka yang menghitung banyaknya pengunjung yang keluar dan masuk ke lokasi konser. Sedangkan LED berfungsi sebagai indikator berupa batasan yang terdiri dari warna hijau yaitu sebagai indikator pengunjung pertama sampai 49. Setelah memasuki pengunjung ke 50 warna LED akan secara otomatis berpindah ke warna kuning sampai ke pengunjung 74.

c. Di pengunjung ke 75 LED secara otomatis akan berpindah kembali menjadi warna merah sampai pengunjung ke 99. Di sini peran buzzer mulai bekerja, jika sudah sampai batas maksimal yaitu 100 pengunjung, maka pengunjung yang masuk ke 101 tidak di izinkan masuk dengan tanda buzzer berbunyi.

\subsection{Konsep Dasar Program.}

Menurut Prestiliano, Jasson. (2005), bahasa assembler adalah bahasa komputer yang mempunyai kedudukan di antara bahasa tingkat tinggi dan rendah. Yang dimaksud dengan bahasa tingkat tinggi disini adalah bahasa yang 
menggunakan kata - kata dan pernyataan yang mudah dimengerti oleh manusia. Walaupun jauh berbeda dengan bajasa manusia yang biasa kita gunakan sehari -hari.

Selain penjelasannya, berikut ini ada intruksi dan perintah dalam pemograman assembler, diantaranya :

1. Intruksi DEC.

Singkatannya adalah Decrement, intruski yang digunakan untuk menurunkan suatu nilai (1 byte) yang tersimpan dalam salah satu dari empat macam : akumulator, register, nilai langsung dan tak langsung melalui register, sebesar 1. Bila nilai awal $00 \mathrm{~h}$, maka setelah di intruksi hasilnya adalah FFh. Tidak ada flag yang terpengaruh. Berikut contoh empat macam kemungkinan intruksi DEC :

Contoh:

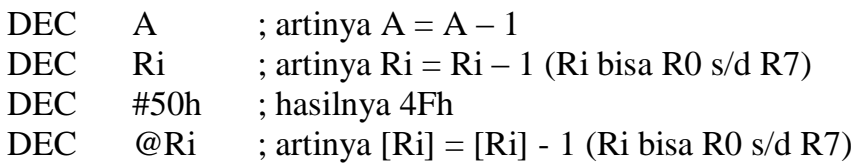

2. Intruksi INC.

Intruksi INC (Increment) adalah kebalikan dari intruksi DEC. Karena intruksi INC digunakan untuk menaikkan nilai (1 byte juga) sebesar 1. Bila sebelumnya nilai awal adalah FFh, maka hasilnya adalah 00h.

Jika intruksi ini digunakan untuk mengubah keluaran suatu Port, maka nilai awal dari Port yang bersangkutan berasal dari pengancing data keluaran, bukan pin - pin masukan.

Berikut contoh empat macam kemungkinan intruksi INC :

Contoh:

INC A $\quad ;$ artinya $\mathrm{A}=\mathrm{A}+1$

INC Ri $\quad$ artinya $\mathrm{Ri}=\mathrm{Ri}+1(\mathrm{Ri}$ bisa R0 s/d R7)

INC $\quad \# 50 \mathrm{~h}$; hasilnya $51 \mathrm{~h}$

INC @Ri ; artinya [Ri] = [Ri] + $1($ Ri bisa R0 s/d R7)

3. Intruksi RET.

Intruksi RET atau disebut juga Return ialah perintah yang digunakan untuk kembali dari suatu rutin layanan interupsi. Selain RET ada pula RETI. Perbedaan intruksi. RETI adalah memberitahukan kepada sistem kontrol interupsi bahwa interupsi yang sedang dikerjakan telah selesai. Jika tidak ada saat RETI dieksekusi, maka fungsinya sama dengan RET.

4. Intruksi CALL.

Perintah CALL disini sebagai pemanggil dan dapat menyimpan suatu register tertentu. Perintah CALL sendiri pun mempunyai dua intruksi, diantaranya ada LCALL dan ACALL. Dua perintah tersebut ada yang berbeda dalam format alamat subrutin yang diberikan ke CPU. CALL merupakan mnemonic yang umum yang dapat digunakan jika pemrogram tak peduli bagaimana alamat dikodekan. Berikut dari perintah CALL :

Syntax : CALL NamaP

5. Intruksi JMP (JUMP).

JMP atau JUMP yang artinya disebut intruksi - intruksi lompatan tanpa syarat. Namun JMP itu sendiri ialah intruksi atau mnemonic umum yang digunakan jika pembuatnya tidak peduli bagaimana intruksi JMP akan dikodekan nantinya. Pada kenyataannya, intruksi ini terdiri dari tiga. Diantaranya ada SJMP (Short Jump) berukuran 3 byte, LJMP (Long Jump) berukuran 2 byte dan AJMP (Absolute Jump) berukuran 2 byte. Masing masing intruksi ini berbeda dalam format alamat tujuannya. Kode - kode yang dijalankan bisa dituliskan sebagai berikut :

Misal: MOV DPTR,\#JUMP_TABLE

MOV A,INDEX_NUMBER

RL A

JMP@A+DPTR

6. Intruksi DJNZ.

Intruksi DJNZ (Decrement and Jump if Not Zero) ini merupakan intruksi yang akan mengurangi 1 nilai register serbaguna (R0..R7) atau memori data. Selanjutnya akan lompat ke memori program yang dituju jika ternyata 
setelah pengurangan 1 tersebut hasilnya tidak nol. Berikut ini merupakan contoh potongan program untuk membentuk waktu tunda secara sederhana :

Contoh : MOV R0,\#23h

DJNZ R0,\$

7. Intruksi CJNE.

Intruksi CJNE (Compare and Jump if Not Equal) membandingkan dua nilai yang disebut dan MCS akan lompat ke memori program yang dituju bila kedua nilai tersebut tidak sama. Berikut perintah intruksi dari CJNE, ialah :

Misal : MOV A,P1

CJNE A,\#0Ah,TidakSama

...

SJMP EXIT

;

TidakSama:

$\ldots$

8. Perintah SBB.

SBB atau Substract With Carry digunakan pada operasi pengurangan dengan bilangan yang besar (lebih dari 16 bit), dengan cara memberi perintah SUB disertai dengan SBB. Dalam Perintah SBB :

Syntax : SBB Tujuan,Asal

9. Perintah SUB.

Untuk Operasi pengurangan dapat digunakan perintah SUB. Perintah SUB akan mengurangkan nilai pada Tujuan dengan Asal. Hasil yang didapat akan ditaruh pada Tujuan. Isi pada perintah SUB :

Syntax : SUB Tujuan,Asal

10. Perintah ADD.

Untuk menambah dalam bahasa assembler digunakan perintah ADD. Perintah ADD ialah :

Syntax : ADD Tujuan,Asal

Perintah ADD ini akan menambahkan nilai pada Tujuan dan Asal. Hasil yang didapat akan ditaruh pada Tujuan, dalam bahasa pascal sama dengan instruksi Tujuan:=Tujuan + Asal. Sebagai contohnya :

Contoh

$$
\begin{array}{lll}
\text { : MOV } & \text { AH,15h } & ; \text { AH:=15h } \\
\text { MOV AL,4 } & ; \text { AL:=4 } & \\
\text { ADD } & \text { AH,AL } & ; A H:=A H+A L, \text { jadi } A H=19 h
\end{array}
$$

11. Perintah ADC.

Penggunaan perintah ADC mirip dengan perintah ADD, yaitu :

Syntax : ADC Tujuan,Asal

Perbedaannya ialah tujuan tempat menampung hasil pertambahan Tujuan dan Asal ditambah lagi dengan carry flag (Tujuan:=Tujuan+Asal+Carry). Pertambahan yang demikian bisa memecahkan masalah seperti yang pernah kita kemukakan, misal pertambahan pada bilangan 12345678h+9ABCDEF0h. Seperti yang telah kita ketahui bahwa satu register hanya mampu menampung 16 bit, maka untuk pertambahan seperti yang diatas bisa kamu

\begin{tabular}{|c|c|c|c|}
\hline \multirow[t]{6}{*}{ Contoh } & MOV & $\mathrm{AX}, 1234 \mathrm{~h}$ & $; A X=1234 h \quad C F=0$ \\
\hline & MOV & $\mathrm{BX}, 9 \mathrm{ABCh}$ & $; \mathrm{BX}=9 \mathrm{ABCh} \mathrm{CF}=$ \\
\hline & MOV & $\mathrm{CX}, 5678 \mathrm{~h}$ & $; \mathrm{BX}=5678 \mathrm{~h} C \mathrm{CF}=0$ \\
\hline & MOV & DX,0DEF0h & ; DX $=$ DEF0h $\mathrm{CF}=0$ \\
\hline & ADD & \multicolumn{2}{|c|}{$\mathrm{CX}, \mathrm{DX} ; \mathrm{CX}=3568 \mathrm{~h} \mathrm{CF}=1$} \\
\hline & $\mathrm{ADC}$ & $\mathrm{AX}, \mathrm{BX} ; \mathrm{A} 工$ & $\mathrm{AX}+\mathrm{BX}+\mathrm{CF}=\mathrm{ACF} 1$ \\
\hline
\end{tabular}
gunakan perintah ADC untuk memecahkannya.

Berikut ini contoh dari perintah $\mathrm{ADC}$ :

12. Perintah LOOP.

Perintah LOOP digunakan untuk melakukan suatu proses yang berulang - ulang. Adapun syntax dari perintah ini serta tujuan dapat berupa suatu label yang telah didefinisikan, adalah : 
Contoh

$$
\begin{array}{lll}
: & \text { MOV CX,3 } & \text {; Banyaknya pengulangan yang dilakukan } \\
\text { Ulang: } & \text { INT 10h } & \text {; Tempat terjadinya pengulangan } \\
& \text { LOOP Ulang } & \text {; Lompat ke label 'Ulang' }
\end{array}
$$

13. Operasi Perkalian.

Untuk perkalian bisa digunakan perintah MUL dengan syntax :

Syntax : MUL Sumber

14. Operasi Pembagian.

Operasi pada pembagian pada dasarnya sama dengan perkalian. Untuk operasi pembagian digunakan perintah DIV dengan syntax :

Syntax : DIV Sumber

15. Intruksi MOV.

Intruksi ini adalah intruksi yang digunakan sebagai penyalin data dari satu operand ke operand lainnya atau bisa disebut intruksi transfer data. Berikut ini intruksi dari MOV :

$\begin{array}{llll}\text { Syntax } & \text { MOV } & \text { tujuan,Asal } \\ \text { Contoh } & \text { MOV } & \text { AL,9 } & \text {; masukkan nilai } 9 \text { pada AL } \\ & \text { MOV } & \text { AH,AL } ; \text { nilai } A L=9 \text { dan } A H=9 \\ & \text { MOV } & \text { AX,9 } & ; A X=A H+A L \text { hingga } A H=0 \text { dan } A L:=9\end{array}$

\section{ANALISA DAN PEMBAHASAN}

Berikut ini fungsi dari Alat Penghitung Jumlah Pengunjung Konser Berbasis Mikrokontroler AT89S51 adalah :

a. Fungsi pertama ialah untuk mendapatkan hitungan data secara otomatis.

b. Fungsi kedua ialah untuk mempercepat penghitungan.

c. Fungsi ketiga ialah untuk memperkecil kesalahan pada penghitungan secara manual.

d. Fungsi keempat ialah agar mendapatkan hasil yang akurat dan signifikan.

e. Dan masih banyak fungsi - fungsi lainya.

Selain itu adapun cara kerja dari Alat Penghitung Jumlah Pengunjung Konser Berbasis Mikrokontroler AT89S51 secara umum adalah :

a. Pertama, seseorang akan melewati pintu masuk ke dalam suatu tempat konser. Di bagian pintu masuk tersebut terdapat sensor infrared. Sensor infrared ini bekerja untuk seberapa banyak benda yang melewati sinarnya sebanyak yang telah ditentukan.

b. Kedua, hasil pendeteksian akan masuk dan terhitung secara otomatis. Begitupun seterusnya sampai orang orang selanjutnya. Kemudian hasil seberapa jumlah pengunjung yang masuk akan dikeluarkan berupa angka melalui seven segment.

c. Ketiga, adapun lampu bewarna hijau, kuning dan merah di daerah pintu sebagai pengingat dan penanda. Lampu - lampu yang ada memiliki masing - masing penyimpanan status angka. Lampu warna hijau berkisar 0 - 49 orang, kuning berkisar 50 - 74, dan merah berkisar $75-99$.

d. Keempat, bila seseorang masuk diangka 99 berarti orang selanjutnya diangka 100 dilarang masuk dengan tanda buzzer berbunyi. Buzzer disini digunakan sebagai alarm yang menandakan bahwa pengunjung telah mencapai batas maksimal. Agar suara buzzer bisa mati orang terakhir yang melewati pintu masuk harus melewatin pintu keluar.

e. Kelima, pada pintu keluar terpasang sensor inframerah sama seperti pintu masuk hanya saja sensor ini bekerja berbanding terbalik pada sensor masuk. Siapa saja yang melewatinya akan mengurangi angka yang ada pada seven segment.

f. Keenam, pada pintu keluar angka pada seven segment akan berkurang dan buzzer akan berhenti berbunyi. Selain itu lampu pun akan bergerak sesuai status angka yang sudah diatur pada program alat tersebut dan mengikuti cara sebaliknya (mirip seperti pintu masuk).

\subsection{Blok Diagram Alat.}

Berikut ini adalah gambar blok diagram pada Alat Penghitung Jumlah Pengunjung Konser Berbasis Mikrokontroler AT89S51: 


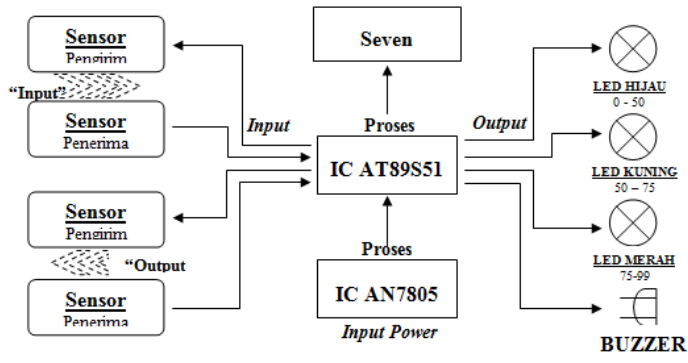

Gambar 19. Blog Diagram Alat

Berikut merupakan rancangan program flowchart.

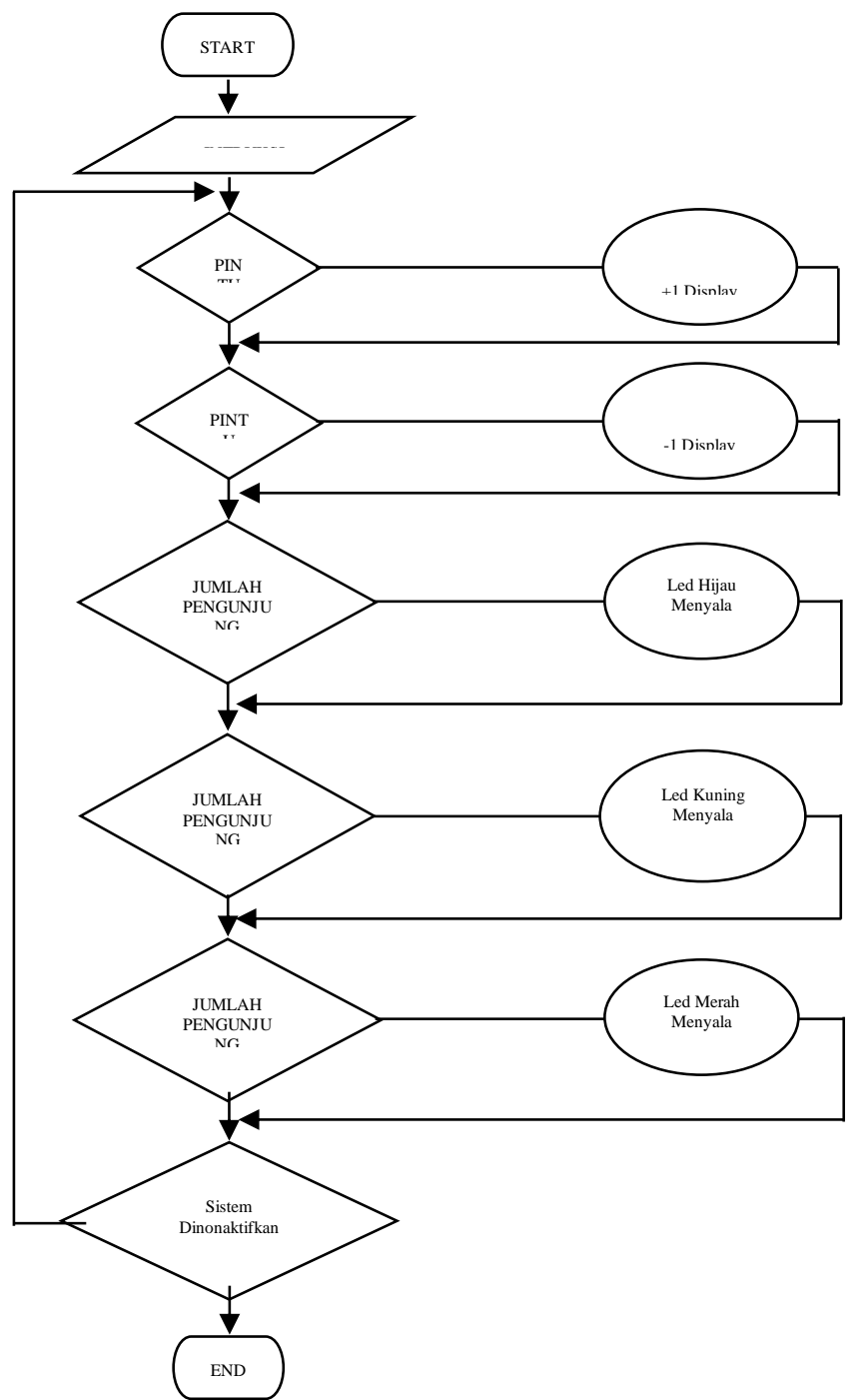

Gambar 20. Rancangan Flowchart

Berikut ini penjelasan langkah dalam flowchart program, diantaranya :

1. Flowchart Start, Intruksi Sistem, Pintu Masuk, +1 Display.

Penjelasan dari bagian flowchart yang pertama adalah memulai penulisan program lalu membuat inisialisasi sistem pada bagian input yaitu sensor, sistem minimum dan output berupa tampilan led dan jumlah pengunjung lewat seven segment. Pendeteksian sensor masuk untuk mengetahui adanya pengunjung yang masuk ke tempat konser dimana sensor tersebut terhalangi oleh tubuh manusia sehingga data tersebut terkirim 
ke mikrokontroler. Setelah itu mikrokontroler akan mendapatkan inputan adanya pengunjung yg masuk lalu menampilkan jumlah pengunjung lewat tampilan seven segment berupa angka.

2. Pintu Keluar, -1 Display.

Sensor kedua untuk mendeteksi adanya pengunjung yang keluar apabila sensor tersebut terhalangi dan mengirim ke mikrokontroler sehingga mikrokontroler mengurangi data pengunjung yang masuk melalui tampilan seven segment.

3. Jumlah Pengunjung < 50, Led Hijau Menyala.

Tampilan led hijau menunjukkan banyaknya pengunjung yang masuk sekitar 49 orang yang berarti masih banyak tempat yang tersisa.

4. Jumlah Pengunjung $>50<75$, Led Kuning Menyala.

Led kuning menyala menunjukkan pengunjung mulai banyak masuk ke lokasi konser. Pada jumlah ini dimulai dari angka 50 orang sampai 74 orang yang berarti tempat yang tersisa makin menipis.

5. Jumlah Pengunjung $74-99$, Led Merah Menyala.

Semakin banyaknya pengunjung yang masuk dan terdeksi oleh sensor yang terletak di pintu masuk yang menyebabkan led merah menyala menandakan bahwa pengunjung telah memadati tempat konser sehingga dinyatakan penuh.

6. Sistem Dinonaktifkan, End.

Apabila ada yang keluar dan terdeteksi oleh sensor maka angka pada tampilan seven segment menunjukkan adanya pengunjung yang keluar dan tampilan kembali ke semula.

\subsection{Konstruksi Sistem (Coding).}

Pada pembahasan konstruksi sistem atau coding, dalam pembuatan listing program digunakanlah bahasa assembler. Bahasa assembler disini sebagai penulisan set intruksi serta di compiler untuk menghasilkan file tipe ".hex" (hexsadesimal) yang akan di download ke dalam sebuah IC Mikrokontroler. Listing program disini meliputi program seven segment, sensor infrared, program lampu led peringatan dan program alarm suara buzzer. Selain itu adapun langkah - langkah dalam pembuatan didalamnya, diantaranya sebagai berikut :

a. Program pertama digunakanlah software Notepad dari windows 7. Penggunaan disini untuk membuat file coding assembler untuk disimpan dalam bentuk file bertipe ".ASM". Contoh berikut ini file di save dengan nama "Konser.ASM".

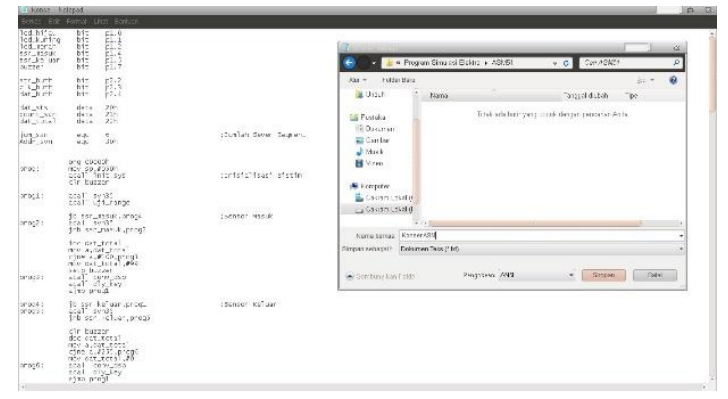

Gambar 21. Pengetikan program pada notepad

b. Langkah selanjutnya ialah compile file "Konser.ASM" tadi lewat software ASM51, dengan cara ketik "Konser" lalu tekan "enter". ASM51 merupakan compiler untuk melakukan perubahan listing program Assembler ke dalam format hex (hexsadesimal).

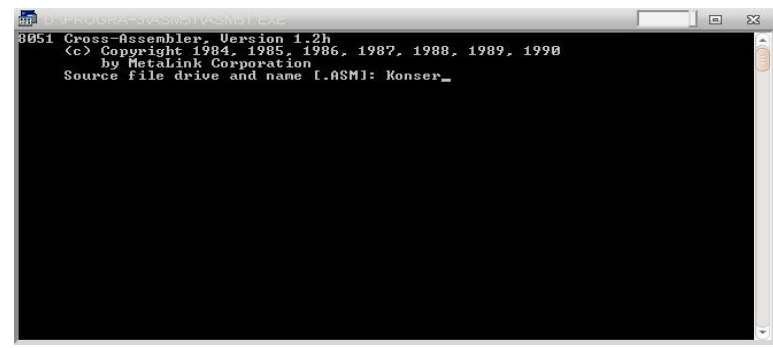

Gambar 22. Pengujian pada DOS Prompt 
c. Setelah di compiler, berikut ini hasil proses selesai dalam folder program ASM51 pada Windows Explore :

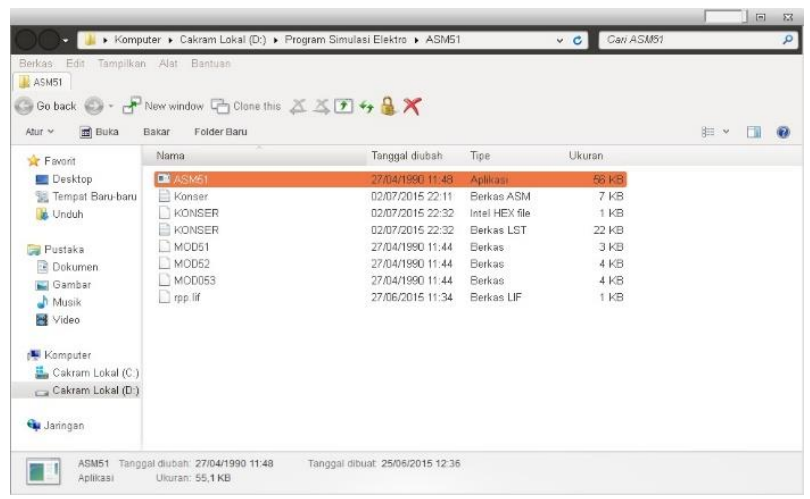

Gambar 23. Windows Explorer

d. Di dalam Windows Explorer tadi, hasil yang dimaksud cuma tiga jenis file. Diantaranya ada "ASM ( yang merupakan penulisan set intruksi)", "HEX (file berjenis kode atau bahasa mesin)", dan "LST (merupakan bentuk hasil penyimpanan dan kode)".

\begin{tabular}{|lllr} 
Nama & Tanggal diubah & Tipe & \multicolumn{1}{c}{ Ukuran } \\
\hline Konser & $0207 / 201522: 11$ & Berkas ASM & 7 KB \\
\hline KONSER & $02017 / 201522: 32$ & Intel HEX file & 1 KB \\
K KONSER & $0207 / 201522: 32$ & Berkas LST & 22 KB
\end{tabular}

Gambar 24. Tiga Jenis Tipe File

e. Dalam mendownload program coding ke IC Mikrokontroler, digunakan software PROGISP beserta interface Komputer melalui I/O. Cara menggunakan software ini pilih IC Mikrokontroler yang dipakai (misal : AT89S51) dan masukan coding file bertipe "HEX" dengan klik "File" pilh "Load Flash". Lalu anda mulailah melakukan download.

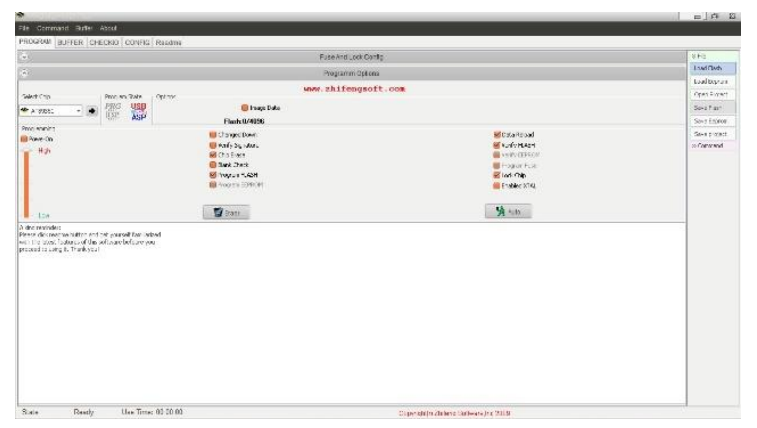

Gambar 25. PROGISP

Disini kami melakukan tes selesai hasil uji coba pada alat yang kami buat yaitu "Alat Penghitung Jumlah Pengunjung Konser Berbasis Mikrokontroler AT89S51”. Berikut rinciannya :

a. Uji coba penghitungan pintu masuk.

Tabel 5. Uji Coba Penghitungan Pintu Masuk

\begin{tabular}{|l|c|c|c|c|}
\hline \multicolumn{2}{|c|}{ Pintu Masuk } & & \\
\cline { 1 - 2 } $\begin{array}{c}\text { Sensor } \\
\text { Pengirim }\end{array}$ & $\begin{array}{c}\text { Sensor } \\
\text { Peneri } \\
\text { ma }\end{array}$ & $\begin{array}{c}\text { Seven } \\
\text { Segmen }\end{array}$ & LED & Buzzer \\
\hline $\begin{array}{l}\text { Mendeteksi } \\
\text { Sampai 49 }\end{array}$ & $0-49$ & Hijau & Tidak Bunyi \\
\hline \multicolumn{2}{|l|}{ Mendeteksi 50 } & 50 & Kuning & Tidak Bunyi \\
\hline
\end{tabular}




\begin{tabular}{|l|c|c|c|c|}
\hline \multicolumn{2}{|c|}{ Pintu Masuk } & & \\
\cline { 1 - 2 } $\begin{array}{c}\text { Sensor } \\
\text { Pengirim }\end{array}$ & $\begin{array}{c}\text { Sensor } \\
\text { Peneri } \\
\text { ma }\end{array}$ & $\begin{array}{c}\text { Seven } \\
\text { Segmen }\end{array}$ & LED & Buzzer \\
\hline $\begin{array}{l}\text { Mendeteksi 51 } \\
\text { Sampai 74 }\end{array}$ & $51-74$ & Kuning & Tidak Bunyi \\
\hline Mendeteksi 75 & 75 & Merah & Tidak Bunyi \\
\hline $\begin{array}{l}\text { Mendeteksi 76 } \\
\text { Sampai 99 }\end{array}$ & $76-99$ & Merah & Tidak Bunyi \\
\hline Mendeteksi 99 & 99 & Merah & Tidak Bunyi \\
\hline Mendeteksi 100 & 100 & Merah & Bunyi \\
\hline
\end{tabular}

b. Uji coba penghitungan pintu keluar.

Tabel 6. Uji Coba Penghitungan Pintu Keluar

\begin{tabular}{|c|c|c|c|c|}
\hline \multicolumn{2}{|c|}{ Pintu Keluar } & \multirow{2}{*}{$\begin{array}{c}\text { Seven } \\
\text { Segmen }\end{array}$} & \multirow{2}{*}{ LED } & \multirow{2}{*}{ Buzzer } \\
\hline $\begin{array}{c}\text { Sensor } \\
\text { Pengirim }\end{array}$ & Sensor Penerima & & & \\
\hline \multicolumn{2}{|c|}{ Mendeteksi 100} & 100 & Merah & Bunyi \\
\hline \multicolumn{2}{|c|}{ Mendeteksi 99} & 99 & Merah & Tidak Bunyi \\
\hline \multicolumn{2}{|c|}{ Mendeteksi 99 Sampai 76} & $99-76$ & Merah & Tidak Bunyi \\
\hline \multicolumn{2}{|c|}{ Mendeteksi 75} & 75 & Merah & Tidak Bunyi \\
\hline \multicolumn{2}{|c|}{ Mendeteksi 74 Sampai 51} & $74-51$ & Kuning & Tidak Bunyi \\
\hline \multicolumn{2}{|c|}{ Mendeteksi 50} & 50 & Kuning & Tidak Bunyi \\
\hline \multicolumn{2}{|c|}{ Mendeteksi 49 Sampai 0} & $49-0$ & Hijau & Tidak Bunyi \\
\hline
\end{tabular}

\section{KESIMPULAN}

Dari pembahasan pada pembuatan Alat Penghitung Jumlah Pengunjung Konser Berbasis Mikrokontroler AT89S51 ini, maka diambil kesimpulan :

1. Dengan adanya alat ini, bisa membantu pekerjaan manusia dan pengganti posisi jalannya kerja secara manual.

2. Peran alat ini dalam suatu perusahaan sangat penting, karena dapat meng-input data secara otomatis kedalam suatu sistem tertentu.

3. Dengan adanya alat ini, diharapkan bisa membantu memberi inspirasi pada pembaca dan membuat suatu pilihan dalam alat yang lainnya dan mencoba mengembangkannya ke yang lebih baik.

4. Game yang dirancang dapat melatih kecepatan berfikir pemain karena memiliki batas waktu dalam permainannya

Adapun saran yang penulis berikan, yaitu:

1. Pada bagian sensor, sebaiknya menggunakan sensor PIR. Dikarenakan agar saat mendeteksi bisa bekerja dengan sempurna.

2. Pada bagian seven segment, sebaiknya menggunakan layar LCD. Penggunaan layar LCD bisa melihat jumlah pengunjung yang lebih jelas dan baik.

3. Pada bagian buzzer, sebaiknya diganti dengan speaker. Penggantian buzzer dengan speaker kemungkinan akan lebih jelas suaranya bila dibandingkan dari suara buzzer yang kurang begitu besar suaranya.

\section{REFERENCES}

[1] ST, Malik Ibnu Moh., 2006. Pengantar Membuat Robot. Yogyakarta: Penerbit Gava Media

[2] Tim Pustena ITB. 2011. Jurus Kilat Jago Membuat Robot. Bekasi: Dunia Komputer

[3] Putra Eko Agfianto. 2004. Belajar Mikrokontroler AT89C51/52/55. Yogyakarta: Penerbit Gava Media

[4] Prestiliano, Jasson. 2005. Strategi Bahasa Assembler. Yogyakarta: Penerbit Gava Media

[5] ST, Malik Ibnu Moh., 2003. Belajar Mikrokontroler ATMEL AT89S8252. Yogyakarta: Penerbit Gava Media 